\title{
Study of Image Enhancement Techniques in Image Processing: A Review
}

\author{
Ramandeep Kaur ${ }^{\text {a }}$, Kamaljit Kaur ${ }^{\text {b }}$ \\ ${ }^{a}$ Student, Village Urdhan,Tehsil Ajnala, Amritsar ,Punjab and 143103, India \\ ${ }^{b}$ Assistant Professor, Department Computer Engineering and Technology, Guru Nanak Dev University, \\ Amritsar, Punjab and 143001, India
}

\begin{abstract}
Image denoising plays extremely important role in digital image processing. The primary objective of this paper is to explore highlighted challenges of the image filtering techniques. The comprehensive study has evidently shown that the one of most challenging issue in image filtering is edge preserving while removing the noise. Because edges deliver the most important information to the human visual system. This paper has compared different recent image filtering methods based upon certain factors. The comparisons have shown that the noise reduction using wavelet coefficients based on OMP has quite effective improvements over available methods. Challenging issue in image filtering technique is removing the multiplicative noise and high density of noises is still found.
\end{abstract}

Index Terms: Image denoising, Over Complete Dictionary, Orthogonal Matching Pursuit (OMP) and Wavelet Coefficients based on Orthogonal Matching Pursuit (WCOMP).

(C) 2016 Published by MECS Publisher. Selection and/or peer review under responsibility of the Research Association of Modern Education and Computer Science.

\section{Introduction}

Digital Image Processing is a wide field which provides the different fundamentals for the digital image. A digital image is really a depiction of two dimensional images as a finite group of digital values. It concentrates on two important tasks. Primary is a pictorial data for human elucidation. Next is finalizing of image data with regard to storage, transmission and illustration for autonomous machine observation. Digital image is double dimensional image consists of a finite quantity of element all of with a particular position and value. These elements are referred to as picture element, image element, pels or pixels. The pixel is a smallest controllable element of a picture represented on the screen. There are five main fundamentals include in digital image processing. And the image enhancement is one of most commonly used class of Image Processing operations.

* Corresponding author. Tel.:

E-mail address: 
The most important function of the image enhancement is to improve the quality of the image, reduce the noise content, and sharpen the image detail. It is subjective to the observer and the image. It is only to emphasize certain feature of interest in an image. An instance of enhancement is while raise the contrast of an image for the reason that "it looks better or improved." Tasks involved in this similar to

- Brightness

- Contrast Adjustment

- Edge Enhancement

- Noise Reduction

- Filtering

Under the image enhancement in recent years the technology of the remote sensing is growing rapidly and with this making it possible to offer a huge quantity of spatial information for the remote sensing image analysis applications like target detection[23] and sub pixel mapping [23]. Remote sensing is the acquisition of information regarding an object not including physical contact among the object. The remote sensing images are basically disturbed by sensor noise, absorption, atmospheric scattering which reduce the image visual quality[1].

The noise is the outsider element of image which occurs variation in the image quality similar to brightness, color intensity etc. In digital image processing, various types of noises are to be removed by different methods. The noise in the image decreases the performance of visual image quality and computerized analysis [3]. The process of getting the better original image as of the noisy image is called as image reconstruction. The reconstruction of the image require the sample of the image as of which the original image is improved [5]. Noise is an unwanted signal in digital images. It produces the undesirable effects such as unseen lines, unrealistic edges, corners, disturb background scenes and blurred objects. There are different types of noise in image processing some are defining below:-

\section{- Gaussian noise}

In this each pixel in the image distorted by the little quantity from the original intensity value of the image. It is as well called a normal noise. It's having modeled for represent this kind of noise that is called Gaussian distribution. The ' $\mathrm{p}$ ' probability density function of a Gaussian random ' $z$ ' variable is known by:

$$
p(z)=\frac{1}{\sqrt{2 \pi \sigma}} e^{-\left(\mathrm{z}_{\mathrm{z}}\right) 2 / 2 \sigma^{2}}
$$

Where $\mathrm{z}$ represents intensity, $\mu$ the mean value and $\sigma$ the standard deviation, the standard deviation $\sigma^{2}$ is called the variance of $\mathrm{z}$.

\section{- Impulse noise}

It is also called the salt and pepper noise. This type of noise occurring in white and black pixels in the image. For this noise median filter is very effective noise reduction method. The probability density function for impulse noise is known by:

$$
p(z)=\left\{\begin{array}{cc}
P a & \text { for } z=a \\
P b & \text { for } z=b \\
0 & \text { otherwise }
\end{array}\right\}
$$

If $\mathrm{b}>\mathrm{a}$, intensity $\mathrm{b}$ will be come out like a light point in an image and a will be come out like a dark point in 
an image. If $\mathrm{Pa}$ or $\mathrm{Pb}=0$, the impulse noise is called the unipolor.

\section{- Poisson noise}

Poisson noise is an electronic noise which can be modeled by a poisson process. It occurs in optical devices and originates from electric charge. It is basically removed by median filter.

\section{- Speckle noise}

It is a granular noise and degrades the quality of the medical ultrasound and radar images. These suffer from common phenomenon called speckle that are like bright and dark dots in an image. The adaptive filter model is used for this type of noise reduction [3].

Many strategies have been used to reduce the noise of a remote sensing image[1 Sparse representation will be the most widely used representation involving images in addition to signals for most applications related to image processing and signal. Some of these applications consist of things like image filtering, feature extraction, edge detection and picture compression and many others. The Sparse representation is truly what represents this signal using the few volume of elementary atom. It necessitate the technique of the overcomplete dictionary in which elementary atom filled by means of dictionary. The overcomplete dictionary involves the fundamental atoms employed for reconstruction intent. The Orthogonal Matching Pursuit (OMP) algorithm can be a best alternative for signal recovery. [5]. And other various approaches are used to recover the signal including OMP algorithm, Matching Pursuits [24], K-SVD algorithm which is used in a various fields like denoising, updating the dictionary and compressing image. It has achieved good results. [12]. Another technique is Multiscale Geometric Analysis such as Curvelet [22], Contourlet [8], and Gabor Dictionaries are basically used for restoration of textures [15]. And the wavelet coefficients based on OMP (WCOMP). In this introduce the coefficients of wavelet transform into a greedy strategy that are combine with OMP algorithm to improve the performance of the image compare to another approaches. In this paper OMP algorithm combine with K-SVD decomposition with the DCT (discrete cosine transform) to achieve the sparse representation of the image and after reconstruct this image. The goal of this method is to improve the final performance of the image noise reduction. The WCOMP method performs better than the conventional image denoising methods such as wavelet, Contourlet and K-SVD [1]. It is under the image enhancement fundamental of the digital image processing.

The work in this paper has been organized as follows: Section 2 presents the different image enhancement approaches and divides the different approaches into different categories. These categories are presented in the tabular form. Section 3 has presented the parameterized comparison of selected strategies under image enhancement. Section 4 presents the various challenges occur in image enhancement noise reduction techniques. Finally Section 5 presents the conclusions of overall paper and discuss about the scope of future.

\section{Approaches for Image Enhancement and Related Work}

It is a wide and first fundamental in image processing. There are different categories arise under the image enhancement. Basically three categories are highlighted like Contrast, Noise Reduction or Filtering.

\subsection{Contrast enhancement}

Contrast is an important factor of image quality. It is the subjective to the observer. It is evaluated by the difference in the brightness and color of the object background objects. There are many methods used for contrast enhancement have been developed and then applied to issues and problems in image processing. Xiwen Liu proposed the new fuzzy enhancement operator and continuous membership function for solving the issues in traditional old fuzzy algorithm. Proposed method enhances the quality of the image and improves 
image edges [28]. Shailendra Singh Negi and Yatendra Singh Bhandari have proposed the Image Sharpening and Contrast Stretching techniques for boundary enhancement, noise, and contrast adjustment. Proposed method improves the contrast, adjust the contrast and enhance the boundaries of the image [31]. Vaishali Ahirwar and Himanshu Yadav proposed the Hybrid Model(DCT, DWT) for preserving the brightness of the digital image. This hybrid technique removes the noise, preserve the brightness and enhance the contrast of the image[30].

Table 1. Different Techniques of the Contrast under the Image Enhancement Are Below

\begin{tabular}{|c|c|c|c|c|}
\hline $\begin{array}{l}\text { Contrast enhancement } \\
\text { technique/algorithm }\end{array}$ & Operating domain & Quality metrics & Transform & Limitations \\
\hline
\end{tabular}

\begin{tabular}{|c|c|c|c|c|c|}
\hline $\begin{array}{l}\text { Adaptive unsharp } \\
\text { mask algorithm } \\
(\text { AUM)[26] }\end{array}$ & Spatial domain & Contrast, local mean & NA & $\begin{array}{l}\text { Enhance the high } \\
\text { detail area of } \\
\text { medical images }\end{array}$ & $\begin{array}{l}\text { No sharp the edges } \\
\text { and not work on low } \\
\text { area details }\end{array}$ \\
\hline $\begin{array}{l}\text { Laplacian filter in } \\
\text { AUM[27] }\end{array}$ & Spatial domain & MSEI,PSNR & NA & $\begin{array}{l}\text { It produces the } \\
\text { better edge } \\
\text { sharpness and } \\
\text { contrast adjustment }\end{array}$ & $\begin{array}{l}\text { It only focus on the } \\
\text { edges sharpness }\end{array}$ \\
\hline $\begin{array}{l}\text { Improved Image } \\
\text { Enhancement } \\
\text { Algorithm[28] }\end{array}$ & Spatial domain & Contrast, histogram & $\begin{array}{l}\text { Fuzzy } \\
\text { based }\end{array}$ & $\begin{array}{l}\text { Increase the contrast } \\
\text { of the image and } \\
\text { also enhance the } \\
\text { edges and blur of } \\
\text { the image }\end{array}$ & $\begin{array}{l}\text { It will good result } \\
\text { after two or three } \\
\text { times enhance the } \\
\text { image not only once } \\
\text { time }\end{array}$ \\
\hline $\begin{array}{l}\text { Histogram } \\
\text { equalization[29] }\end{array}$ & Spatial domain & PSNR, AMBE & NA & $\begin{array}{l}\text { It generate the high } \\
\text { quality contrast } \\
\text { enhancement image } \\
\text { without losing the } \\
\text { image features }\end{array}$ & $\begin{array}{l}\text { Lead to degraded } \\
\text { edges }\end{array}$ \\
\hline Hybrid model[30] & $\begin{array}{l}\text { Frequency } \\
\text { domain }\end{array}$ & PSNR,MSE & $\begin{array}{l}\text { Frequency } \\
\text { based- } \\
\text { DCT,DWT }\end{array}$ & $\begin{array}{l}\text { It preserve the } \\
\text { brightness and } \\
\text { enhance the visual } \\
\text { quality of the digital } \\
\text { image }\end{array}$ & $\begin{array}{l}\text { Lead to degraded } \\
\text { edges }\end{array}$ \\
\hline $\begin{array}{l}\text { Image sharpening and } \\
\text { contrast } \\
\text { stretching[31] }\end{array}$ & Spatial domain & $\begin{array}{l}\text { Histogram, } \\
\text { laplacian mask }\end{array}$ & NA & $\begin{array}{l}\text { It is simultaneously } \\
\text { enhances } \\
\text { boundaries and } \\
\text { adjust the contrast } \\
\text { and provide good } \\
\text { quality }\end{array}$ & $\begin{array}{l}\text { Lead to degraded } \\
\text { edges }\end{array}$ \\
\hline
\end{tabular}

\subsection{Noise reduction or filtering}


Noise reduction would be the main technique of removing noise from the image. There are a variety of noise are generally arise inside image including uniform noise, gaussian noise, salt and pepper noise, gamma noise, poisson noise and speckle noise.. There are many methods used for noise reduction in enhancement have been developed and then applied to issues and problems in image processing. Jean-Luc Starck and Emmanuel J. Candes proposed the curvelet transform technique for the noise removal in the signal or image which is exact reconstruction of the image by remove the noise in the image [22]. Xia La, Liangpei Zhang at el describes the new three stage haze removal algorithm for the single image haze removal by remote sensing. Proposed method recovers the image from the blur and noise of the image [6]. Joel A. Tropp proposed the OMP algorithm for solve the issues of the signal recovery from random measurements. This new algorithm provides the faster and easier implementation for the signal recovery problems in the image [12]. Filtering is the basic process or function which is used to attain the several tasks for instance noise reduction and filters are used to eliminate the noise as of the image by using different types of filters such as mean filter and median filter. There are many methods used for filtering in image enhancement have been developed and then applied to issues and problems in image processing. Tieyong Zeng and Francois Malgouyres has proposed the Gabor Dictionaries for solve the issue image denoising. By this Gabor filter obtained better results [15]. Marian Kazubek proposed a thresholding and wiener filtering for the image denoising which denoise the image and increase the performance with the thresholding method [20]. Michael Elad and Matan Protter proposed the KSVD algorithm for the image denoising. The proposed technique K-SVD algorithm provides the improved result as contrast to other strategies for denoising and improves denoising performance [9]. There are more different techniques and algorithms for different issues in the noise reductions or filtering some are spatial domain and some are frequency domain in image enhancement are define below.

Table 2. Spatial Domain Based Techniques under the Noise Reduction Are Given Below

\begin{tabular}{|c|c|c|c|c|c|c|}
\hline $\begin{array}{l}\text { Noise reduction } \\
\text { enhancement } \\
\text { technique/algorithm }\end{array}$ & $\begin{array}{l}\text { Operating } \\
\text { domain }\end{array}$ & Noise type & $\begin{array}{l}\text { Quality } \\
\text { metrics }\end{array}$ & $\begin{array}{l}\text { Transform } \\
\text { based }\end{array}$ & Features & Limitations \\
\hline $\begin{array}{l}\text { Neighbour wavelet } \\
\text { coefficient } \\
\text { dependency[32] }\end{array}$ & $\begin{array}{l}\text { Spatial } \\
\text { domain }\end{array}$ & $\begin{array}{l}\text { Gaussian } \\
\text { White noise }\end{array}$ & PSNR & NA & $\begin{array}{l}\text { Remove the noise by } \\
\text { threshold and } \\
\text { customized } \\
\text { wavelet filter by } \\
\text { using Simulated } \\
\text { Annealing } \\
\text { At the same time. }\end{array}$ & $\begin{array}{l}\text { Not work in } \\
\text { Multi wavelets in } \\
\text { image denoising }\end{array}$ \\
\hline $\begin{array}{l}\text { Denoising and } \\
\text { enhancing for } \\
\text { mammographic } \\
\text { images[33] }\end{array}$ & $\begin{array}{l}\text { Spatial } \\
\text { domain }\end{array}$ & $\begin{array}{l}\text { Gaussian } \\
\text { noise }\end{array}$ & $\begin{array}{l}\text { Local } \\
\text { contrast, } \\
\text { histogram }\end{array}$ & NA & $\begin{array}{l}\text { It is useful for noise } \\
\text { removal and enhance } \\
\text { the edge and local } \\
\text { contrast }\end{array}$ & $\begin{array}{l}\text { Extend the } \\
\text { denoising technique } \\
\text { Include non- } \\
\text { Gaussian noise. }\end{array}$ \\
\hline $\begin{array}{l}\text { Fuzzy impulse } \\
\text { noise detection and } \\
\text { reduction method } \\
\text { (FIDRM)[34] }\end{array}$ & $\begin{array}{l}\text { Spatial } \\
\text { domain }\end{array}$ & $\begin{array}{l}\text { Impulse and } \\
\text { Gaussian } \\
\text { noise }\end{array}$ & PSNR & $\begin{array}{l}\text { Fuzzy } \\
\text { Based }\end{array}$ & $\begin{array}{l}\text { Remove the impulse } \\
\text { noise and leave that } \\
\text { pixels which are noise } \\
\text { free }\end{array}$ & $\begin{array}{l}\text { Very low execution } \\
\text { time }\end{array}$ \\
\hline $\begin{array}{l}\text { Two pass hybrid } \\
\text { method[35] }\end{array}$ & $\begin{array}{l}\text { Spatial } \\
\text { domain }\end{array}$ & Impulse noise & MSE & $\begin{array}{l}\text { Neural } \\
\text { network } \\
\text { based }\end{array}$ & $\begin{array}{l}\text { Remove the impulse } \\
\text { noise in efficient } \\
\text { manner and works } \\
\text { better than other } \\
\text { methods are } \\
\text { compared }\end{array}$ & $\begin{array}{l}\text { Expand the existing } \\
\text { method and use } \\
\text { other detectors and } \\
\text { the use the better } \\
\text { estimators in highly } \\
\text { corrupted impulse } \\
\text { noise. }\end{array}$ \\
\hline
\end{tabular}




\begin{tabular}{|c|c|c|c|c|c|c|}
\hline $\begin{array}{l}\text { Curvelet and } \\
\text { wavelet } \\
\text { transform[36] }\end{array}$ & $\begin{array}{l}\text { Spatial } \\
\text { domain }\end{array}$ & $\begin{array}{l}\text { Gaussian } \\
\text { noise } \\
\text { (additive } \\
\text { noise ) } \\
\text { Speckle noise } \\
\text { (multiplicative } \\
\text { noise ) }\end{array}$ & $\begin{array}{l}\text { SNR, } \\
\text { PSNR }\end{array}$ & $\begin{array}{l}\text { Fuzzy } \\
\text { Based }\end{array}$ & $\begin{array}{l}\text { It provides the better } \\
\text { smoothness in image } \\
\text { background while } \\
\text { keeping the edge } \\
\text { preserved and } \\
\text { removal the fuzzy } \\
\text { edges }\end{array}$ & $\begin{array}{l}\text { Not affected true } \\
\text { edges }\end{array}$ \\
\hline $\begin{array}{l}\text { Improve } \\
\text { neighshrink } \\
\text { method[37] }\end{array}$ & $\begin{array}{l}\text { Spatial } \\
\text { domain }\end{array}$ & $\begin{array}{l}\text { Gaussian } \\
\text { noise }\end{array}$ & PSNR & NA & $\begin{array}{l}\text { Remove the noise and } \\
\text { improve the denoising } \\
\text { performance }\end{array}$ & $\begin{array}{l}\text { Lead to degraded } \\
\text { edges }\end{array}$ \\
\hline $\begin{array}{l}\text { Exponential } \\
\text { mixture models for } \\
\text { Noise reduction[38] }\end{array}$ & $\begin{array}{l}\text { Spatial } \\
\text { domain }\end{array}$ & $\begin{array}{l}\text { Gaussian } \\
\text { noise }\end{array}$ & $\begin{array}{l}\text { Least mean } \\
\text { square error }\end{array}$ & NA & $\begin{array}{l}\text { Remove the noise } \\
\text { from observed data } \\
\text { for clustering and } \\
\text { improve the } \\
\text { performance }\end{array}$ & $\begin{array}{l}\text { Lead to degraded } \\
\text { edges }\end{array}$ \\
\hline $\begin{array}{l}\text { Adaptive filter } \\
\text { algorithm[44] }\end{array}$ & $\begin{array}{l}\text { Spatial } \\
\text { domain }\end{array}$ & Speckle noise & $\begin{array}{l}\text { MSE, } \\
\text { MMSE }\end{array}$ & NA & $\begin{array}{l}\text { Eliminates the noise } \\
\text { from radar images by } \\
\text { adaptive filter }\end{array}$ & $\begin{array}{l}\text { Need to } \\
\text { develop the edge } \\
\text { detection algorithm } \\
\text { for radar images }\end{array}$ \\
\hline $\begin{array}{l}\text { Context based } \\
\text { filtering[46] }\end{array}$ & $\begin{array}{l}\text { Spatial } \\
\text { domain }\end{array}$ & $\begin{array}{l}\text { Gaussian } \\
\text { noise }\end{array}$ & OCR & NA & $\begin{array}{l}\text { Remove the noise } \\
\text { from images and loss } \\
\text { the compression } \\
\text { performance due to } \\
\text { preserving the quality } \\
\text { of the image and } \\
\text { OCR accuracy }\end{array}$ & $\begin{array}{l}\text { Lead to degraded } \\
\text { edges }\end{array}$ \\
\hline $\begin{array}{l}\text { Median filter for } \\
\text { color image } \\
\text { enhancement[47] }\end{array}$ & $\begin{array}{l}\text { Spatial } \\
\text { domain }\end{array}$ & $\begin{array}{l}\text { Gaussian } \\
\text { noise }\end{array}$ & Contrast & NA & $\begin{array}{l}\text { Eliminates the noise } \\
\text { from the color images } \\
\text { by chromaticity } \\
\text { diffusion }\end{array}$ & $\begin{array}{l}\text { Not preserve the } \\
\text { edges }\end{array}$ \\
\hline $\begin{array}{l}\text { Hybrid method } \\
\text { using cellular } \\
\text { automata and } \\
\text { fuzzy logic[42] }\end{array}$ & $\begin{array}{l}\text { Spatial } \\
\text { domain }\end{array}$ & Impulse noise & $\begin{array}{l}\text { PSNR, } \\
\text { MSE }\end{array}$ & $\begin{array}{l}\text { Fuzzy } \\
\text { Based }\end{array}$ & $\begin{array}{l}\text { Remove the impulse } \\
\text { noise. It is very } \\
\text { simple and robust }\end{array}$ & $\begin{array}{l}\text { Not work efficient } \\
\text { on high noisy } \\
\text { images }\end{array}$ \\
\hline $\begin{array}{l}\text { Rank ordered } \\
\text { filter[51] }\end{array}$ & $\begin{array}{l}\text { Spatial } \\
\text { domain }\end{array}$ & NA & $\begin{array}{l}\text { Contrast, } \\
\text { histogram }\end{array}$ & $\begin{array}{l}\text { Fuzzy } \\
\text { Based }\end{array}$ & $\begin{array}{l}\text { It provide the better } \\
\text { edge, boundaries } \\
\text { enhancement and } \\
\text { edge detection }\end{array}$ & $\begin{array}{l}\text { Not work on the } \\
\text { low contrast areas }\end{array}$ \\
\hline $\begin{array}{l}\text { Neuro-fuzzy } \\
\text { network based } \\
\text { Filtering[53] }\end{array}$ & $\begin{array}{l}\text { Spatial } \\
\text { domain }\end{array}$ & Impulse noise & MSE.PSNR & $\begin{array}{l}\text { Neuro- } \\
\text { fuzzy } \\
\text { based }\end{array}$ & $\begin{array}{l}\text { Reduce the noise and } \\
\text { improve the } \\
\text { optimization } \\
\text { performance, easier } \\
\text { implementations }\end{array}$ & $\begin{array}{l}\text { Not work well on } \\
\text { low contrast areas }\end{array}$ \\
\hline
\end{tabular}


Table 3. Frequency Domain Based Techniques under the Noise Reduction Are Given Below

\begin{tabular}{|c|c|c|c|c|c|c|}
\hline $\begin{array}{l}\text { Filtering } \\
\text { enhancement } \\
\text { technique/algorithm }\end{array}$ & $\begin{array}{l}\text { Operating } \\
\text { domain }\end{array}$ & Noise type & $\begin{array}{l}\text { Quality } \\
\text { metrics }\end{array}$ & $\begin{array}{l}\text { Transform } \\
\text { based }\end{array}$ & Features & Limitations \\
\hline $\begin{array}{l}\text { Noise Filtering } \\
\text { by Use of Local } \\
\text { Statistics[43] }\end{array}$ & $\begin{array}{l}\text { Frequency } \\
\text { domain }\end{array}$ & $\begin{array}{l}\text { Gaussian } \\
\text { noise, } \\
\text { Speckle } \\
\text { noise }\end{array}$ & MSE & $\begin{array}{l}\text { Frequency } \\
\text { based-FFT }\end{array}$ & $\begin{array}{l}\text { It improve the } \\
\text { contrast } \\
\text { enhancement and } \\
\text { remove the noise } \\
\text { from the image }\end{array}$ & $\begin{array}{l}\text { Extend } \\
\text { the existing } \\
\text { method to } \\
\text { image } \\
\text { restoration and } \\
\text { degradations }\end{array}$ \\
\hline $\begin{array}{l}\text { Wavelet-based image } \\
\text { denoising[39] }\end{array}$ & $\begin{array}{l}\text { Frequency } \\
\text { domain }\end{array}$ & $\begin{array}{l}\text { White } \\
\text { gaussian } \\
\text { noise }\end{array}$ & PSNR & $\begin{array}{l}\text { Frequency } \\
\text { based-DWT }\end{array}$ & $\begin{array}{l}\text { Remove the noise } \\
\text { through thres- } \\
\text { holding }\end{array}$ & $\begin{array}{l}\text { Not Sharp the } \\
\text { edges }\end{array}$ \\
\hline $\begin{array}{l}\text { Fractal } \\
\text { conservation law for } \\
\text { denoising[40] }\end{array}$ & $\begin{array}{l}\text { Frequency } \\
\text { domain }\end{array}$ & $\begin{array}{l}\text { White } \\
\text { gaussian } \\
\text { noise }\end{array}$ & SNR & $\begin{array}{l}\text { Frequency } \\
\text { based-DFT }\end{array}$ & $\begin{array}{l}\text { Simultaneous } \\
\text { denoising and } \\
\text { enhancement. It } \\
\text { amplifies the low } \\
\text { and medium } \\
\text { frequencies and } \\
\text { eliminates the } \\
\text { high frequencies }\end{array}$ & $\begin{array}{l}\text { Lead to } \\
\text { degraded edges }\end{array}$ \\
\hline $\begin{array}{l}\text { Wavelet transform } \\
\text { domain filter[45] }\end{array}$ & $\begin{array}{l}\text { Frequency } \\
\text { domain }\end{array}$ & $\begin{array}{l}\text { White } \\
\text { gaussian } \\
\text { noise }\end{array}$ & SNR & $\begin{array}{l}\text { Frequency } \\
\text { based- FFT }\end{array}$ & $\begin{array}{l}\text { It remove the } \\
\text { noise and } \\
\text { preserve and } \\
\text { sharp the edges }\end{array}$ & $\begin{array}{l}\text { Does not work } \\
\text { on low contrast } \\
\text { background } \\
\text { images }\end{array}$ \\
\hline $\begin{array}{l}\text { Modified Gabor } \\
\text { filter[48] }\end{array}$ & $\begin{array}{l}\text { Frequency } \\
\text { domain }\end{array}$ & $\begin{array}{l}\text { Random } \\
\text { noise }\end{array}$ & TGF,MGF & $\begin{array}{l}\text { Frequency } \\
\text { based-DFT }\end{array}$ & $\begin{array}{l}\text { It enhance the } \\
\text { fingerprint } \\
\text { images and } \\
\text { achieve better } \\
\text { performance }\end{array}$ & $\begin{array}{l}\text { Does not proper } \\
\text { work on edges }\end{array}$ \\
\hline $\begin{array}{l}\text { Modified high pass } \\
\text { filtering method[49] }\end{array}$ & $\begin{array}{l}\text { Frequency } \\
\text { domain }\end{array}$ & $\begin{array}{l}\text { Random } \\
\text { noise }\end{array}$ & Contrast & $\begin{array}{l}\text { Frequency } \\
\text { based-DCT }\end{array}$ & $\begin{array}{l}\text { It sharpen the } \\
\text { image very } \\
\text { efficiently and } \\
\text { useful in color } \\
\text { image sharpness, } \\
\text { remote sensing } \\
\text { and medical } \\
\text { image } \\
\text { enhancement }\end{array}$ & $\begin{array}{l}\text { No work on } \\
\text { little } \\
\text { information } \\
\text { areas }\end{array}$ \\
\hline $\begin{array}{l}\text { Bounded block } \\
\text { matching and } 3 \mathrm{D} \\
\text { filtering[50] }\end{array}$ & $\begin{array}{l}\text { Frequency } \\
\text { domain }\end{array}$ & $\begin{array}{l}\text { White } \\
\text { gaussian } \\
\text { noise }\end{array}$ & PSNR & $\begin{array}{l}\text { Frequency } \\
\text { based-DCT }\end{array}$ & $\begin{array}{l}\text { Remove the noise } \\
\text { from image and } \\
\text { achieve better } \\
\text { visual } \\
\text { performance }\end{array}$ & $\begin{array}{l}\text { Lead to } \\
\text { degraded edges }\end{array}$ \\
\hline $\begin{array}{l}\text { Frequency domain } \\
\text { filtering[52] }\end{array}$ & $\begin{array}{l}\text { Frequency } \\
\text { domain }\end{array}$ & NA & $\begin{array}{l}\text { Canny edge } \\
\text { detector }\end{array}$ & NA & $\begin{array}{l}\text { Improve the } \\
\text { contour detection } \\
\text { performance } \\
\text { from the images } \\
\text { by canny edge } \\
\text { detector }\end{array}$ & $\begin{array}{l}\text { Only work on } \\
\text { edges }\end{array}$ \\
\hline
\end{tabular}




\section{Parameterized Comparison of Selected Strategies under Image Enhancement}

There are different strategies of the image enhancement that have different parameters. These parameters define the each strategy in an efficient manner. There are some techniques are based on spatial domain and some are transform domain. There are very less techniques that are preserve the edges and over-smoothing in noise reduction. There are some techniques working linear and pixel/window based.

Table 4. Different Parameters Working on Different Strategies that are Given Below

\begin{tabular}{|c|c|c|c|c|c|}
\hline $\mathrm{C}_{\text {Strategy }}^{\text {Parameters }}$ & $\begin{array}{l}\text { Spatial/Transform } \\
\text { Domain }\end{array}$ & Edge Preservation & Linear & $\begin{array}{l}\text { Pixel/Window } \\
\text { Based }\end{array}$ & $\begin{array}{l}\text { Over- } \\
\text { smoothing }\end{array}$ \\
\hline $\begin{array}{l}\text { Matching pursuit algorithm } \\
\text { [24] }\end{array}$ & Frequency transform & No & Yes & Window based & No \\
\hline $\begin{array}{l}\text { Sub pixel target detection } \\
{[23]}\end{array}$ & Spatial domain & No & No & Pixel based & No \\
\hline Curvelet Transform [22] & Transform domain & Yes & Yes & Frequency based & No \\
\hline $\begin{array}{l}\text { Scale Mixtures of } \\
\text { gaussians in the wavelet } \\
\text { domain [21] }\end{array}$ & Spatial domain & No & Yes & Window based & No \\
\hline $\begin{array}{l}\text { Morphological } \\
\text { transformations [19] }\end{array}$ & Spatial domain & No & Yes & Window based & No \\
\hline $\begin{array}{l}\text { Thresholding and wiener } \\
\text { filtering [20] }\end{array}$ & Spatial domain & No & Yes & Pixel based & No \\
\hline $\begin{array}{l}\text { Greedy algorithm, } \\
\text { orthogonal matching pursuit } \\
\text { (OMP) [18] }\end{array}$ & Spatial domain & No & Yes & Window based & No \\
\hline $\begin{array}{l}\text { Neighbouring } \\
\text { coefficients [17] }\end{array}$ & Transform domain & No & Yes & Window based & No \\
\hline $\begin{array}{l}\text { Doubly local } \\
\text { wiener filtering [16] }\end{array}$ & Spatial domain & No & Yes & Window based & No \\
\hline K-SVD algorithm[14] & Spatial domain & No & Yes & Window based & No \\
\hline Gabor dictionaries[15] & Transform domain & No & Yes & Window based & No \\
\hline OMP algorithm [12] & Spatial domain & No & Yes & Window based & No \\
\hline SURE-LET approach[13] & Transform domain & No & No & Window based & No \\
\hline $\begin{array}{l}\text { Comparisons of contourlets } \\
\text { curvelets and wavelets [10] }\end{array}$ & Spatial domain & No & Yes & Window based & No \\
\hline $\begin{array}{l}\text { Contourlet using } \\
\text { Adaptive Windows [8] }\end{array}$ & Transform domain & Yes & Yes & Window based & No \\
\hline $\begin{array}{l}\text { Three stage Haze Removal } \\
\text { Algorithm [6] }\end{array}$ & Spatial domain & No & Yes & Window based & No \\
\hline
\end{tabular}




\begin{tabular}{llcccc}
$\begin{array}{l}\text { Wavelet based Techniques } \\
\text { and filtering [3] }\end{array}$ & Spatial domain & Yes & Yes & Window based & No \\
$\begin{array}{l}\text { Patch based wavelet domain } \\
{[2]}\end{array}$ & Spatial domain & Yes & Yes & Window based & No \\
$\begin{array}{l}\text { Wavelet Coefficients based } \\
\text { on OMP [1] }\end{array}$ & Transform domain & No & Yes & Window based & No \\
\hline
\end{tabular}

\section{Various Challenges in Image Enhancement Noise Reduction Techniques}

Image denoising plays extremely important role with digital image processing. There are some most highlighted challenges for the image enhancement that are given below

\section{- Edge preservation}

One of most challenging issue in digital image processing is that the edge preserving while removal the noise from the images because edges deliver the most important information to the human visual system [2].

\section{- High density of noise}

Noise removal is also a one of the biggest challenging issue in the field of digital image processing. Various types of noise exist but the impulse noise elimination is one of the mainly important and necessary preprocessing steps in digital image processing. Impulse noise is type of highest density noise in an image. And what will be effect on the filter due to high density of noise.

\section{- Multiplicative Noise}

Multiplicative noise is most challenging issue in digital image processing. It is also known as speckle noise and very difficult to remove from the images. It considers how the filter give respond to remove this type of noise [54].

\section{Conclusion and Future Work}

Noise removal is found to be one of the biggest challenging issues in the field of digital image processing. Various types of noises exist but the impulsive noise elimination is one of the mainly challenging issue and necessary preprocessing steps in vision processing. The high density of impulsive noise is still an open are of research for vision researchers. This paper has presented various methods used for noise reduction. But none perform best in every case. The OMP based filter is best for the preservation of structure in digital image and it performs well only at low noise level. It does not work for preservation of edges or neighborhood of edges. However, the noise reduction by means of wavelet coefficient based on OMP less effects on the edges than available techniques but not as found in edge preservation techniques.

Therefore in near future we will propose a new technique which will use minimum patch based noise reduction by means of wavelet coefficient lying on OMP technique. To achieve the edge preservation, will select such a patch from noisy image that has minimum patch difference. Thus will have accurate results as not much modification is done in the input patch space i.e. image. However the image gradients will also be used as a post processing operation to preserve the edges in an efficient manner. 


\section{References}

[1] S. Wu.; H. Chenb.; Y. Bai, Z. Zhao;; H. Long.," Remote sensing image noise reduction using wavelet coefficients based on OMP," in Optik 126 (2015) 1439-1444.

[2] P. Jain.; V. Tyagi.," LAPB: Locally adaptive patch-based wavelet domain edge-preserving image denoising", in Information Sciences 294 (2015) 164-181.

[3] A.; Jaiswala.; J. Upadhyayb.; A. Somkuwar.," Image denoising and quality measurements by using filtering and wavelet based techniques", in Int. J. Electron. Commun. (AEU) xxx (2014).

[4] A. Tanchenko.," Visual-PSNR measure of image quality", in J. Vis. Commun. Image R. 25 (2014) 874878, http://dx.doi.org/10.1016/j.jvcir.2014.01.008.

[5] Suchithra, M.; Sukanya, P.; Prabha, P.; Sikha, O.K.; Sowmya, V.; Soman, K.P., "An experimental study on application of Orthogonal Matching Pursuit algorithm for image denoising," in Automation, Computing, Communication, Control and Compressed Sensing (iMac4s), 2013 International MultiConference on, vol., no., pp.729-736, 22-23 March 2013.

[6] X. Lan, H. Shen, L. Zhang," Single image haze removal considering sensor blur and noise," EURASIP J. Adv. Signal Process. 86 (2013), http://dx.doi.org/10.1186/1687-6180-2013-86.

[7] Lihong Yang; Jianyue Ren, "Remote sensing image restoration using estimated point spread function," in Information Networking and Automation (ICINA), 2010 International Conference on,vol.1,no.,pp.V1-48-V1-52,18-19Oct.2010.

[8] Zuofeng Zhou; Jianzhong Cao; Weihua Liu, "Contourlet-based image denoising algorithm using adaptive windows," in Industrial Electronics and Applications, 2009. ICIEA 2009. 4th IEEE Conference on, vol., no., pp.3654-3657, 25-27 May 2009.

[9] Protter, M.; Elad, M., "Image Sequence Denoising via Sparse and Redundant Representations," in Image Processing, IEEE Transactions on, vol.18, no.1, pp.27-35, Jan. 2009.

[10] H. Shan.; J. Ma.; H. Yang.," Comparisons of wavelets, contourlets and curvelets in seismic denoising", Journal of Applied Geophysics 69 (2009) 103-115, doi:10.1016/j.jappgeo.2009.08.002.

[11] Mairal, J.; Elad, M.; Sapiro, G., "Sparse Representation for Color Image Restoration," in Image Processing, IEEE Transactions on, vol.17, no.1, pp.53-69, Jan. 2008.

[12] Tropp, J.A.; Gilbert, A.C., "Signal Recovery From Random Measurements Via Orthogonal Matching Pursuit," in Information Theory, IEEE Transactions on, vol.53, no.12, pp.4655-4666, Dec. 2007.

[13] Blu, T.; Luisier, F., "The SURE-LET Approach to Image Denoising," in Image Processing, IEEE Transactions on, vol.16, no.11, pp.2778-2786, Nov. 2007.

[14] Aharon, M.; Elad, M.; Bruckstein, A., "K-SVD: An Algorithm for Designing Overcomplete Dictionaries for Sparse Representation," in Signal Processing, IEEE Transactions on, vol.54, no.11, pp.4311-4322, Nov. 2006.

[15] Tieyong Zeng; Malgouyres, F., "Using Gabor Dictionaries in A TV - L ${ }^{\infty}$ Model, for Denoising," in Acoustics, Speech and Signal Processing, 2006. ICASSP 2006 Proceedings. 2006 IEEE International Conference on, vol.2, no., pp.II-II, 14-19 May 2006.

[16] Peng-Lang Shui, "Image denoising algorithm via doubly local Wiener filtering with directional windows in wavelet domain," in Signal Processing Letters, IEEE, vol.12, no.10, pp.681-684, Oct. 2005.

[17] Chen, G.Y.; Bui, T.D.; Krzyzak, A., "Image denoising using neighboring wavelet coefficients," in Acoustics, Speech, and Signal Processing, 2004. Proceedings. (ICASSP '04). IEEE International Conference on, vol.2, no., pp.ii-917-20 vol.2, 17-21 May 2004.

[18] J.A. Tropp, Greed is good: algorithmic results for sparse approximation, IEEETrans. Inf. Theory 50 (10) (2004) 2231-2242.

[19] Benediktsson, J.A.; Pesaresi, Martino; Amason, K., "Classification and feature extraction for remote sensing images from urban areas based on morphological transformations," in Geoscience and Remote 
Sensing, IEEE Transactions on, vol.41, no.9, pp.1940-1949, Sept. 2003.

[20] Kazubek, M., "Wavelet domain image denoising by thresholding and Wiener filtering," in Signal Processing Letters, IEEE, vol.10, no.11, pp.324-326, Nov. 2003.

[21] Portilla, J.; Strela, V.; Wainwright, M.J.; Simoncelli, E.P., "Image denoising using scale mixtures of Gaussians in the wavelet domain," in Image Processing, IEEE Transactions on , vol.12, no.11, pp.13381351, Nov. 2003.

[22] Starck, J.-L.; Candes, E.J.; Donoho, D.L., "The curvelet transform for image denoising," inImage Processing, IEEE Transactions on, vol.11, no.6, pp.670-684, Jun 2002, doi: 10.1109/TIP.2002.1014998.

[23] Chein-I Chang; Heinz, D.C., "Constrained subpixel target detection for remotely sensed imagery," in Geoscience and Remote Sensing, IEEE Transactions on, vol.38, no.3, pp.1144-1159, May 2000,doi: $10.1109 / 36.843007$.

[24] Mallat, S.G.; Zhang, Z., "Matching pursuits with time-frequency dictionaries," in Signal Processing, IEEE Transactions on, vol.41, no.12, pp.3397-3415, Dec 1993 doi: 10.1109/78.258082.

[25] Pati, Y.C.; Rezaiifar, R.; Krishnaprasad, P.S., "Orthogonal matching pursuit: recursive function approximation with applications to wavelet decomposition," in Signals, Systems and Computers, 1993. 1993 Conference Record of The Twenty-Seventh Asilomar Conference on, vol., no., pp.40-44vol.1, 1Nov1993.

[26] Tian Xiurong, "The application of adaptive unsharp mask algorithm in medical image enhancement," in Cross Strait Quad-Regional Radio Science and Wireless Technology Conference (CSQRWC), 2011, vol.2, no., pp.1368-1370, 26-30 July 2011.

[27] H. Gokhan Ilk.; Onur Jane.; Ozlem _Ilk. "The effect of Laplacian filter in adaptive unsharp masking for infrared image enhancement", in Infrared Physics \& Technology 54 (2011) 427-438.

[28] Xiwen Liu.," An Improved Image Enhancement Algorithm Based on Fuzzy Set", 2012 International Conference on Medical Physics and Biomedical Engineering, Physics Procedia 33 (2012) 790 - 797.

[29] Shih-Chia Huang. Chien HuiYeh., "Image contrast enhancement for preserving mean brightness without losing image features", in Engineering Applications of Artificial Intelligence 26 (2013) 1487-1492.

[30] Ahirwar, V.; Yadav, H.; Jain, A., "Hybrid model for preserving brightness over the digital image processing," in Computer and Communication Technology (ICCCT), 2013 4th International Conference on, vol., no., pp.48-53, 20-22 Sept. 2013.

[31] Negi, S.S.; Bhandari, Y.S., "A hybrid approach to Image Enhancement using Contrast Stretching on Image Sharpening and the analysis of various cases arising using histogram," in Recent Advances and Innovations in Engineering (ICRAIE), 2014, vol., no., pp.1-6, 9-11 May 2014.

[32] G.Y. Chen.; T.D. Bui.; A. Krzy zak., "Image denoising withneigh bour dependency and customized wavelet and threshold", in Pattern Recognition 38 (2005) 115 - 124.

[33] Jacob Scharcanski; Claudio Rosito Jung.," Denoising and enhancing digital mammographic images for visual screening" in Computerized Medical Imaging and Graphics 30 (2006) 243-254.

[34] Schulte, S.; Nachtegael, M.; De Witte, V.; Van der Weken, D.; Kerre, E.E., "A fuzzy impulse noise detection and reduction method," in Image Processing, IEEE Transactions on, vol.15, no.5, pp.11531162, May 2006.

[35] Rezvanian, A.; Faez, K.; Mahmoudi, F., "A two-pass method to impulse noise reduction from digital images based on neural networks," in Electrical and Computer Engineering, 2008. ICECE 2008. International Conference on, vol., no., pp.400-405, 20-22 Dec. 2008.

[36] G.G. Bhutada.; R.S. Anand.; S.C. Saxena., "Edge preserved image enhancement using adaptive fusion of images denoised by wavelet and curvelet transform," in Digital Signal Processing 21 (2011) 118-130.

[37] Dengwen Z.; Wengang C.," Image denoising with an optimal threshold and neighbouring window," in Pattern Recognition Letters 29 (2008) 1694-1697.

[38] Dehao Ren; Wenzao Li, "An exponential mixture models for noise reduction in clustering," in Communication Software and Networks (ICCSN), 2011 IEEE 3rd International Conference on, vol., no., pp.457-461, 27-29 May 2011. 
[39] Xiao F.; Zhang Y., "A Comparative Study on Thresholding Methods in Waveletbased Image Denoising," in Procedia Engineering 15 (2011) 3998 - 4003.

[40] Azerad P.; Bouharguane A., "Simultaneous denoising and enhancement of signals by a fractal conservation law," in Commun Nonlinear Sic Number Simulat 17 (2012) 867-881.

[41] Jin W., "Wavelet domain denoising method based on multistage median filtering," in April 2013, 20(2): $113-119$.

[42] Sadeghi S.; Rezvanian A.; Kamrani E., "An efficient method for impulse noise reduction from images using fuzzy cellular automata," in Int. J. Electron. Commun. (AEÜ) 66 (2012) 772- 779.

[43] Jong-Sen Lee, "Digital Image Enhancement and Noise Filtering by Use of Local Statistics," in Pattern Analysis and Machine Intelligence, IEEE Transactions on, vol.PAMI-2, no.2, pp.165-168, March 1980.

[44] Frost, Victor S.; Stiles, Josephine Abbott; Shanmugan, K.S.; Holtzman, J., "A Model for Radar Images and Its Application to Adaptive Digital Filtering of Multiplicative Noise," in Pattern Analysis and Machine Intelligence, IEEE Transactions on, vol.PAMI-4, no.2, pp.157-166, March 1982.

[45] Xu, Y.; Weaver, J.B.; Healy, D.M., Jr.; Lu, J., "Wavelet transform domain filters: a spatially selective noise filtration technique," in Image Processing, IEEE Transactions on, vol.3, no.6, pp.747-758, Nov 1994.

[46] Ageenko E.; Franti P., "Context-based Filtering of document images," in Pattern Recognition Letters 21 (2000) 483-491.

[47] Tang, B.; Sapiro, G.; Caselles, V., "Color image enhancement via chromaticity diffusion," in Image Processing, IEEE Transactions on, vol.10, no.5, pp.701-707, May 2001.

[48] Yang J.; Liu L.; Jiang T.; Fan Y., "A modified Gabor filter design method for fingerprint image enhancement," in Pattern Recognition Letters 24 (2003) 1805-1817.

[49] Yang C.C.; "Image enhancement by the modified high-pass filtering approach," in Optik 120 (2009) 886-889.

[50] Chen Q.; Wu D., "Image denoising by bounded block matching and 3D filtering" in Signal Processing 90 (2010) 2778-2783.

[51] Chaira T., "A rank ordered filter for medical image edge enhancement and detection using intuitionistic fuzzy set," in Applied Soft Computing 12 (2012) 1259-1266.

[52] Qu Z.; Wang P. et al., "Frequency domain filtering of gradient image for contour detection," in Optik $\mathrm{xxx}(2012) \mathrm{xxx}-\mathrm{xxx}$.

[53] Li Y.; Sun J.; Luo H., "A neuro-fuzzy network based impulse noise filtering for gray scale images," in Neurocomputing127 (2014)190-199.

[54] Yu-Mei Huang; Moisan, L.; Ng, M.K.; Tieyong Zeng, "Multiplicative Noise Removal via a Learned Dictionary," in Image Processing, IEEE Transactions on, vol.21, no.11, pp.4534-4543, Nov. 2012.

\section{Authors' Profiles}

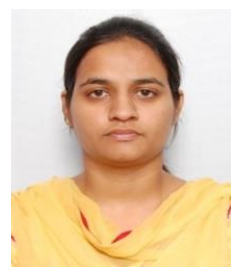

Ramandeep Kaur (born June 14, 1993) is a Student, Pursuing M.tech in Software System at Computer Engineering and Technology Department, Guru Nanak Dev University Amritsar. Her main interest area is digital image processing. 


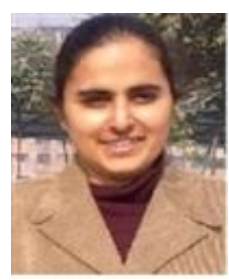

Kamaljit Kaur (born December 15, 1985) is an Assistant Professor at Computer Engineering and Technology Department, Guru Nanak Dev University Amritsar. She has completed M.tech in Computer Science and Engineering (2010) with Gold Medalist and currently pursuing PhD at Guru Nanak Dev University Amritsar. Her interest areas are Cloud Computing, Parallel Computing. She has around 22 publications at national and international level.

How to cite this paper: Ramandeep Kaur, Kamaljit Kaur,"Study of Image Enhancement Techniques in Image Processing: A Review", International Journal of Engineering and Manufacturing(IJEM), Vol.6, No.6, pp.38-50, 2016.DOI: 10.5815/ijem.2016.06.04 